\title{
THE LIBRARY OF CONGRESS
}

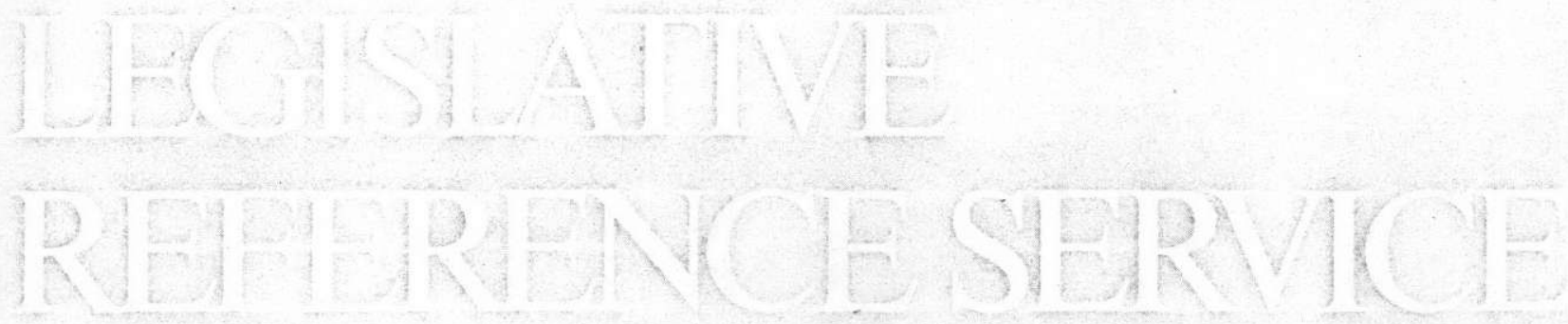

WASHINGTON, D. C.

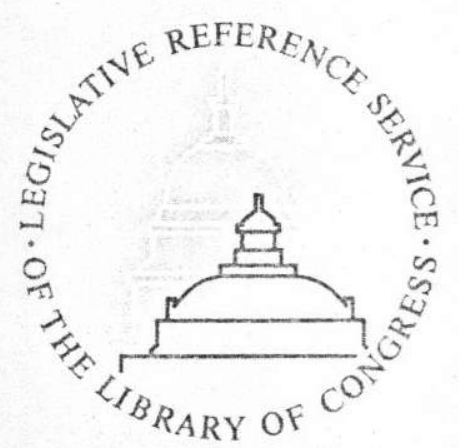

THE STRATEGIC ARMS LIMITATION

TALKS (SALT): A CHRONOLOGY,

JANUARY 1969 - APRIL 1970

LENEICE N. WU

Foreign Affairs Analyst

Foreign Affairs Division

\section{FEB 11971}

GOVT. PUBLICATIONS DEPT.

November 1970 
THE STRATEGIC ARMS LIMITATION TALKS (SALT):

A CHRONOLOGY, JANUARY 1969-APRIL 1970

\section{Introduction}

The opening of the strategic arms limitation talks (SALT) in November 1969 marked the end of several years of diplomatic efforts aimed at the convening of bilateral discussions between the Soviet Union and the United States on curbing the strategic arms race. During the first few months of the Nixon Administration, interest increased in a positive move on the part of the U.S. toward opening the talks. The impact of the August 1968 Soviet invasion of Czechoslovakia had faded somewhat from the public mind, and concern for arms control was heightened by the decision to proceed with the Safeguard ABM system and discussions of U.S. plans for 1970 deployment of multiple independently targetable reentry vehicles (MIRV). After lengthy debate regarding the effect such systems would have on the opening of SALT, the first phase of the Safeguard system was approved in August 1969. A prominent expression of Congressional concern over MIRV was the Brooke resolution, which was introduced in June 1969. It called for a mutual halt in MIRV testing prior to the opening of SALT, to act as a curb on deployment. Because of the difficulties which MIRV could pose for verification of an arms control agreement, deployment of the system was viewed by supporters of the resolution as a stumbling block to success in SALT.

In October 1969 , when it was announced that the two nations had decided to meet, Congressional interest shifted somewhat to remaining informed on 
the progress of the talks, and action on the Brooke resolution was deferred for a time. At that time, it was explained by U.S. officials that the talks were of a preliminary nature, and would be concerned primarily with the mechanics of negotiation -- how to approach the problem, to set up an agenda, if necessary, and to gain insight into the general views of each side on arms limitation, etc. It was stressed that the actual sessions were to be private, and no U.S. proposals or positions were announced. Each country appointed a five-man negotiating team; the Americans were led by Gerard C. Smith, the Director of U.S. Arms Control and Disarmament Agency ( $A C D A)$, and the Soviets by Vladimir S. Semyonov, Deputy Foreign Minister. The preliminary discussions were held in Helsinki between November 17 and December 22, 1969. At their conclusion, it was announced that the two teams would reconvene for substantive discussions on April 16, 1970, in Vienna, and that the talks would be moved back to Helsinki at a later time. The early part of 1970 witnessed further decisions and announcements with regard to U.S. strategic planning. Among them was the announcement by President Nixon in January of his decision to proceed with the second phase of Safeguard. The disclosure in March by Air Force Secretary Seamans of the U.S. intention to begin the scheduled MIRV deployment in June again evoked Congressional criticism of the weapon as a threat to the success of SALT. The culmination of this concern was evidenced by Senate approval of the Brooke resolution, which had been broadened in committee to include a freeze on the deployment of both offensive and defensive strategic weapons systems.

Little has been disclosed regarding the outcome of the Helsinki talks. As was the case during the meetings, the atmosphere was described as 
"constructive" and "businesslike," according to official pronouncements. There were some indications that the Soviets had shown no interest in a MIRV testing moratorium during the preliminary discussions, an assertion made in press reports from unofficial sources. The Vienna talks were expected to provide a forum for actual proposals and bargaining. Rather than a strict agenda for the second phase of SALT, the negotiators had agreed upon a more flexible "work program," which provided broad areas for discussion, but assigned no priority to a particular weapon system or issue. It was generally recognized that while the meetings of the two nations presented some hopeful prospects for arms limitation, the negotiations themselves would be long and difficult, and an agreement would not be instantly forthcoming. The Vienna talks adjourned on August 14, and no formal agreement had been reached. Resumption of the discussions was scheduled for November 2, 1970, in Helsinki.

During both the Helsinki and the Vienna talks, no details of the sessions were disclosed, except for time and place of each meeting. The pattern, as established in Helsinki, was such that the meetings of the two groups alternated between the Soviet and American Embassies; the sessions were held approximately twice a week and the meetings varied in length. At the opening of the talks in Vienna, Ambassador Smith read a statement from President Nixon who expressed "the hope that an agreement can be reached on the limitation and eventual reduction of strategic arsenals with proper recognition of the legitimate security interests of the United States and the Soviet Union and of third countries."

At the time of the October announcement, Secretary of State Rogers said that the negotiations would include "offensive and defensive strategic 
weapons," but declined to state what specific weapons systems were covered by ticas terms. On the whole, official statements regarding the talks have been of this same general nature, and any knowledge as to specific proposals or the progress of the negotiations is rather speculative.

The following chronology seeks to trace the development of the major events of 1969 associated with SALT, through the opening of the Vienna discussions in April 1970. Included in the chronology are some press reports which tend to rely on unofficial sources of information for the details of the negotiations as they develop. I/

1 / Events prior to January 1969 are covered in "Negotiations for Strategic Arms Limitation Talks: A Chronology, January 1964-September 1969." (69-202F) 
$\underline{1969}$

January 14: Melvin Laird, in hearings before the Senate Armed Services Comittee on his appointment as Secretary of Defense, said that the invasion of Czechoslovakia had set back the beginning of strategic arms limitation talks by nine to twelve months. Rejecting the idea of "parity," he stressed that maintaining U.S. superiority in strategic weapons was vital to the U.S. bargaining position.

January 20: In a statement that was interpreted as aimed at the new. U.S. Administration, a spokesman for the Soviet Foreign Ministry, Leonid Zamyatin, in Moscow, issued a declaration of policy on disarmament questions, which covered the same points as a Soviet memorandum of July 1968. With regard to "the mutual limitation and subsequent reduction of strategic means of delivering nuclear weapons, including defensive systems," he reaffirmed that his Government was "prepared to embark on a serious exchange of opinions on this important question." Zamyatin denied that the statement had been timed to coincide with the inauguration of President Nixon. However, he declared that the Soviet Government would come to the conference table "as soon as the Nixon government declares its readiness to do so."

January 27:

In press conference remarks on missile talks, President Nixon introduced the idea that political problems should be included in the context of the discussions. While he favored settling arms questions as well as political ones, he felt that an emphasis on one without consideration of the other would be a mistake. And as one goal of his Administration, he said he wanted to "see to it that we have strategic arms talks in a way and at a time that will promote, if possible, progress on outstanding political problems at the same time." It was also at this first news conference that the President used the term "sufficiency" to describe his Administration's aim in terms of military power, that "our objective is to be sure that the United States has sufficient military power to defend our interests and to maintain the commitments which this Administration determines are in the interest of the United States around the world." 
February 13: Acting Director Adrian Fisher submitted the Eighth Annual Report of ACDA to President Nixon, in which several events during the calendar year 1968 were mentioned for their contribution to negotiations which were aimed at slowing down the nuclear arms race. The report mentioned President Johnson's remark at the signing ceremonies of the Non Proliferation Treaty (NPT) that talks were to be forthcoming "on the limftation and reduction of both offensive strategic nuclear weapons delivery systems and systems of defense against ballistic missiles." The report cited various high-level exchanges with the Soviets (with Ambassador Dobrynin in Washington, the Soviet. Co-Chairman at the ENDC, , and with the Soviet Government in Moscow, by Ambassador Thompson), as positive steps toward the initiation of the talks; however, despite these measures, the invasion of Czechoslovakia had imposed a substantial hindrance to the initiation of discussions. The report also noted the concern throughout the world for the initiation of talks, citing the resolutions of both the Conference of Non-Nuclear-Weapon States and the U.N. General Assembly.

March 4:

During the press conference on his European trip, President Nixon commented on the possibilities of negotiation with the Soviets. Since he had consulted our European allies on the prospects of bilateral discussions with the Soviet Union, the President noted that the next step, "an analysis of the American position -- of our strategic arms capabilities, of our conventional arms capabilities," was underway. "Assuming that those studies go forward on schedule..." he concluded, and there is some "progress on political areas, like the Mideast, then there is... a good possibility that talks [on
strategic arms] could go forward."

March 6:

A response to the argument that deployment of an $A B M$ would escalate the arms race and discourage efforts toward arms control came from ACDA Director Gerard C. Smith in testimony before the Senate Foreign Relations Committee. He pointed out that talks could start within a few months, while it would be several years before the ABM became operational. He also recalled that after the 1967 decision to deploy the Sentinel system, the Russians had sought negotiations, noting that they had more concern for offensive than defensive weapons.

\footnotetext{
- * Eighteen Nation Disarmament Committee.
} 
1969

March 9:

The Senate Foreign Relations Committee report on the NPT was released, advocating ratification of the agreement. With regard to Article VI, the reports summarized the statements by Secretary of State Rogers and Secretary of Defense Laird during hearings on the treaty: "Secretary Rogers, while agreeing that the United States would undertake important commitments under Article VI to pursue seriously and in good faith all efforts to limit the arms race, said he hoped that negotiations to that end would be initiated before the United States deployed a defensive missile system. Secretary Laird stated that the security interests of the United States must dictate the pace of our deployment of offensive and defensive strategic missiles but recognized that Article VI negotiations involve political as well as military questions."

March 10-13: General debate was held in the Senate on the Non-Proliferation Treaty. The approving vote was 83-15.

March 14:

In his announcement of the decision to deploy the Safeguard (ABM) system, President Nixon was asked how the Soviet Union would view this decision and what effect any talks would have on deployment. On the first point, he asserted that because of the defensive nature of the system and the Soviet line of thinking on defensive systems, "the Soviet Union cannot interpret this as escalating the arms race." As for any effect the talks might have on deployment of the weapon, he ruled out the possibility that the ABM would be abandoned entirely by either party, as long as there was a potential threat from Communist China. He added that the preliminaries of the discussions had revealed the talks would involve "only freezing where we are," rather than any reduction in forces.

He added the assurance that each phase of the system would be reviewed "to insure that we are doing as much as necessary but no more than that required by the threat existing at that time." He said that deployment was "closely related to the threat," and that it would be "subject to modification as the threat changes, either through negotiations or through unilateral actions by the Soviet Union or Communist China." 
Ma:cin 20:

In testimony before the Senate Armed Services Committee, Secretary of Defense Laird referred to the "measured deployment" of an ABM as an "added incentive" to negotiate an arms control agreement. He gave two reasons for his statement: (1) that the ABM would show all enemies that they cannot achieve a "low-risk first strike" against the U.S.; and (2) that the U.S. emphasis on defense rejects the idea that this country is striving to achieve a lowrisk first strike capability.

March 27:

Speaking before the Senate Foreign Relations Conittee on major foreign policy issues, Secretary of State Rogers said that preparations for talks on limiting strategic armaments were underway, and that during his recent European trip the President had found U.S. allies "very favorable to the idea." Besides mentioning that the "complex set of issues which will be involved in these talks" was being carefully studied, he hoped that "such talks can begin within the next few months."

He also touched on the recent decision to deploy the Safeguard ABM system and its effect on the talks. During the deliberations prior to the decision the National Security Council had concluded that "the decision would have no adverse effect on disarmament talks." He recalled that just after the announcement to deploy the Sentinel ABM system in 1967, the Soviet Union had agreed to SALT within the following week. With regard to Soviet reaction to the Safeguard decision, he said that in the Soviet message to the ENDC, "there was no indication from Kosygin that it would interfere with the success of those talks." Furthermore, talks with Soviet representatives had not revealed "any suggestion that this decision would affect the initiation of talks or the successful outcome of talks." He added that the talks would consider limitation of both offensive and defensive weapons. In the course of questioning, he went on to say that should arms control talks lead the Soviets to abandon their defensive weapons, the U.S. would act in a like manner.

He reiterated President Nixon's comments to the effect that "one of the principle factors" in the annual review of the Safeguard system "will be the status of talks on the limitation of strategic arms." 
Apri1 18:

Apri1 21:

The subject of the "missile gap" was raised in a press conference by President Nixon, when he pointed out that the U.S. based its policy on Soviet capabilities, and added "when we project their SS-9 plans to 1972 or 1973, if we allow those plans to go forward without taking any action on our part, either offensively or defensively, to counteract them, they will be substantially ahead of the United States in overall nuclear capability." He reminded reporters that the missile gap had been closed by the Soviets and that the United States could not expect to be in a superior position again. While stressing that he did not intend to put an American President in a position where his "diplomatic credibility" would be impaired because the U.S. military capability was in an inferior position, he again used the term "sufficiency" to describe his Administration's military goal.

An indication of the Nixon Administration's goal in the arms talks was given in a New York Times report from Washington that the U.S. would seek a series of limited agreements, rather than a single, comprehensive document. Besides reviewing the background work completed by its predecessor, Nixon's Administration was conducting its own strategic studies. In addition, the format of the talks was expected to differ; while Johnson had planned to initiate the discussions with a summit meeting, then continued by a team of negotiators, Nixon was expected to aim for a less dramatic confrontation, with Gerard C. Smith as the chief negotiator. Thus, the long-range forecast depicted a continual dialogue marked by a succession of specific agreements. It was generally agreed, according to this report, that it was essential to freeze the existing levels of weapons before significant progress could be made on limiting or reducing arms.

April 24:

In the midst of the ABM debate, Senator Edward M. Brooke brought attention to offensive weapons systems, specifically multiple independently targetable re-entry vehicles (MIRV), in a speech before the American Society of Newspaper Publishers. Calling the MIRV concept the "gravest threat... to the possibility of effective arms limitations," he said that "the most urgent task is to limit further operational testing of multiple warhead missiles." Suspension of testing would not require intrusive inspection procedures, and combined with a similar freeze 
LRS-10

1969

April 24:

(cont.)

May 19:

June 1:

June 4: of $\mathrm{ABM}$ systems, the halt in MIRV testing "could create an environment for success in the more detailed and elaborate arms control discussions which must follow."

Congressman Jonathan Bingham introduced a resolution supported by twenty-five cosponsors (the list of supporters was to grow to a total of 107 at the time of hearings on July 8), which called for a suspension of testing involved in the development of multiple independently targeted re-entry vehicle (MIRV) systems. He pointed out the complications which MIRV might present, if successfully developed and deployed, to the inspection of arms control agreements.

A report by the Congressional Conference on the Military Budget and National Priorities, which held meetings in Washington on March 28 and 29, was released, expressing criticism which centered on the military-industrial complex; the report also found issue with MIRV testing and its effect on arms control agreements. In the sixtyone page paper, signed by nine Senators and thirty-six House members, it was stated that "once testing has passed the point where deployment is possible, we can no longer have a self-policing arms agreement with the Russians." In addition, the report declared that once deployment of both the ABM and MIRV was complete, "it is unlikely that the stability we now enjoy will ever return again."

President Nixon reiterated his earlier feelings that arms limitations agreements should be accompanied by settlement of political problems, when he decried the idea that arms control should be "an end in itself." He declared that "the adversaries in the world are not in conflict because they are armed. They are armed because they are in conflict, and have not yet learned peaceful ways to resolve their conflicting national interests."

On the same day, Senator Fulbright speaking before the Joint Congressional Economic Committee called for a halt in the deployment of MIRV and ABM until negotiations have been opened. 
Increased interest in the implications MIRV development would have for arms control was shown in questions put to Secretary of State Rogers, in his second news conference since taking office. Rogers was questioned extensively as to the effect MIRV testing would have on either the start of negotiations or any resulting agreement. When the question was raised "whether or not the testing program itself, by advancing to a certain point, precludes an agreement on preventing the deployment of the MIRVheaded missiles," Rogers said, "I think the answer is No...that won't prevent the talks from being successful and it wouldn't affect the talks, I don't believe."

One reporter pointed out that MIRV might become impossible to negotiate once it had passed a certain point in testing, subsequently leading to deployment. Since reconnaissance satellites would not be able to determine the number of warheads, and they could not be used to verify an agreement, the only alternative would be the mutually unacceptable onsite inspection. Rogers, however, commented that "we' 11 be able to have successful talks whether we have tested MIRV's or not." He reaffirmed the U.S. desire to reach accord with the Soviet Union in arms limitation talks, but, recalling the lengthy time period required to settle on the Non-Proliferation Treaty, he said that "we can't stop our testing on the hope that sometime an agreement would be reached."

June 6:

Secretary of State Rogers testified in a closed session of the Senate Foreign Relations Committee and as a result, according to press reports, there was some change in his position on the effect MIRV testing might have on a strategic arms agreement. Members of the Committee reportedly argued that rather than a reliance on reconnaissance satellites, on-site inspection would be required to verify any control of a MIRV system; this procedure is unacceptable to both the United States and the Soviet Union. Rogers modified his press conference remarks on the previous day, when he conceded that "It might be that if MIRV tests are successful in the next few months, this will present new problems of inspection." Although he would not name a specific date, he adhered to the idea that the beginning of talks could be expected during the summer. 
LRS -12

1969

June 10:

June 13:

Soviet criticism of the Nixon decision to deploy the Safeguard system and its implications for arms control gained more momentum in an articie in Pravda by the newspaper's Washington correspondent Boris G. Strelnikov. The article looked on Nixon's decision as a step toward gaining a position of superiority, to be used as a "trump card" in the impending negotiations. Strelnikov viewed such a position as a stumbling block to agreement, indeed, as a move which would upset the existing strategic balance in the world. He added a reprimand for the delay which had been imposed on a start of talks.

In testimony before the Senate Appropriations Committee, Director of Defense Research and Development Dr. John S. Foster, Jr., told the Committee that both Minuteman 3 and Poseidon equipped with MIRV payloads "are now in the flight test phase." He cited the deployment of MIRV as "a way to insure our ability to penetrate Soviet defenses," particularly to meet the possibility that the Soviet Union might convert its anti-aircraft defense system into one which defends against intercontinental ballistic missiles. Moreover, he said, "We plan to deploy Minuteman 3. It will be equipped with penetration aids as well as multiple warheads. We also plan to deploy Poseidon, which will carry a larger number of multiple warheads."

June 16:

It was reported in the Washington Post that a message from Secretary of State Rogers was delivered to Soviet Ambassador to the United States Anatoly F. Dobrynin on June 11, just prior to Dobrynin's departure for Moscow. Citing Newsweek as its source, the Post said the message suggested July 31 as a target date for the start of SALT talks with the Soviet Union in either Moscow or Geneva. It was also reported that Dobrynin described the message as "good news to take home." However, in a New York Times account, it was pointed out that "United States officials explained that $\mathrm{Mr}$. Roger's remarks to the Ambassador did not constitute a formal proposal of a date or site for the talks." 
June 16:

(cont.)

June 16:

June 17:
According to the Post, Administration officials said the message "did not constitute a firm commitment... but was conditional on approval by President Nixon of Administration proposals for the talks and on successful consultation with the United States West European allies."

The proposal for a moratorium on MIRV development pending initiation of arms talks gained additional support in a statement made by Representative John B. Anderson, chairman of the House Republican Conference. Speaking on the floor of the House, the third-ranking leader of the Republican Party urged the Administration that "the time has come to call a halt to this insane nuclear version of keeping up with the Joneses." Anderson agreed with Nixon's statement in the Air Force Academy speech that "we must take risks for peace--but calculated risks, not foolish risks." However, he added that the key to the President's remarks was the assertion that "We are prepared for new initiatives in the control of arms." Anderson encouraged Nixon to take the initiatives "before it is too late," and stressed the need "to move immediately to the negotiating table with the Russians to work out an acceptable agreement on limitation of nuclear arms."

Senator Brooke introduced a resolution, supported by 39 co-sponsors, urging (1) that the United States Government "seek prompt negotiations with the Union of Soviet Socialist Republics to reach agreement on limiting both offensive and defensive strategic weapons"; (2) that the President should propose to the Soviet Union immediate suspension by both countries "of flight tests of multiple independently targetable reentry vehicles, subject to national verification or such other measures of observation and inspection as may be appropriate"; and (3) that the United States should declare its intention to halt such tests as long as the Soviet
Union did so. 
June 17:

(cont.)
June 19:
Brooke gave two reasons why the present time was considered most opportune for SALT talks: (1) Both the Soviet Union and the United States had achieved "a clear measure" of assured destruction capability, thus, with roughly comparable force levels, they have "entered an era of mutual deterrence," and (2) advanced technology in surveillance had enabled each country to approximate the force levels of the other, and, more significant, could be used to verify compliance with arms control agreements without being intrusive. Keeping these two conditions in mind, he pointed out that both nations had expressed "a serious interest in freezing strategic force levels," and cited this issue as a likely topic of the proposed SALT talks. And he concluded that the continued development of MIRV could prove to be a substantial threat to the favorable atmosphere surrounding the proposed discussions.

In a press conference, President Nixon was asked to name a date for the start of arms talks and the meeting site. In his remarks, he said that "We are just completing our own strategic review"; he noted that the National Security Council had met once and would hold a second meeting to consider further "our position on the SALT talks." He added that time for "consultations with our allies" would require the balance of June and into July. He named July 31 as a target date, and affirmed that Secretary of State Rogers had so informed Dobrynin. However, he pointed out, "We have not had a reply from them." Once the various consultations had been completed, he hoped that "sometime between July 31st and the 15th of August there would be a meeting." With regard to location, he mentioned Geneva or Vienna as possible sites, but maintained "We are open on that question."

Asked to comment on the possibility of a MIRV test moratorium, he said that it was being considered "as part of any arms control agreement." However, he emphasized that a unilateral halt would not be in the interests of the United States, and asserted, "Only in the event that the Soviet Union and we could agree that a moratorium on tests could be mutually beneficial to us, would we be able to agree to do so." Nixon described the resolution advanced by Senator Brooke and others as "constructive insofar as they themselves are thinking 
1969

June 27:

It was reported by the Associated Press that the United States delegation at the SALT talks would consist of five negotiators, headed by Gerard C. Smith, Director of ACDA, with Philip Farley as his alternate. Farley, a Deputy Assistant Secretary of State and expert in nuclear arms policy, was expected to be appointed as Deputy Director of the Arms Control and Disarmament Agency. The remaining members of the team would be: Paul H. Nitze, former Deputy Secretary of Defense (designated as a consultant); Dr. Harold Brown, former Air Force Secretary; Major General Royal B. Allison, arms control specialist with the Joint Chiefs of Staff; and Llewellyn Thompson, former United States Ambassador to Moscow. Official White House announcement was not released until July 5 .

July 1:

A Washington Post report from Brussels indicated that United States NATO allies were "becoming increasingly impatient to see Washington fulfill its promise that United States officials will consult with them before talks begin on strategic arms limitation." The article recalled Nixon's pledge (made in February during his visit to NATO headquarters) that the United States would consult its allies both before and during the negotiations. However, the report pointed out that the first of a series of Council meetings prior to the talks was held the previous day, with no United States officials in attendance; but, it explained, "it is understood that the United States document that sets out the objectives of the talks has not been completed." Specific reference was made to the two concerns of the West Germans, as to how any future agreement would affect either (1) the Russian medium range missile force aimed at West Germany, or (2) the United States weapons "deployed specifically to destroy these targets."

Ju1y 10:

In a major foreign policy statement to the Supreme Soviet, Soviet Foreign Minister Gromyko referred to relations with the United States in what was described by United States commentators as a "conciliatory tone." Concerning the possibility of SALT talks with the United States, Gromyko affirmed the Soviet readiness "to start an exchange of opinions with the United States over socalled strategic weapons," and expressed "the hope that the two sides will approach this question bearing in mind its paramount importance." 
Philip Farley, newly appointed Deputy Director of ACDA, : testified before a House Foreign Affairs subcommittee, where he suggested that MIRV development might have progressed to the point where a moratorium would be neither instrumental in preventing deployment, nor feasible, especially in terms of United States security. In the course of his testimony, he sought to make a distinction between two types of MIRV, and the role of each in the strategic balance. On the other hand, the United States might require MIRV as "a means of maintaining a retaliatory capability, through their capability of penetrating potential heavy ABM defense of cities." However, he also pointed out "they can be a threat to a retaliatory capability and thus to the maintenance of a stable state of mutual deterrence, thereby increasing the need for $A B M$ defense of retaliatory forces." Taking these differences into consideration, it was brought out that in the context of an arms control agreement, the treatment of the MIRV concept could vary. According to the New York Times account of the testimony, Farley seemed to imply that "while the Administration might favor prohibition on the development of MIRV's accurate enough to strike at missiles on the other side, it would not necessarily favor a curb on less accurate MIRV's designed only to penetrate defenses around cities." (Yet Farley did not explain how the distinction might be made in an agreement.)

As an additional stumbling block to a moratorium on testing of MIRV Farley did not rule out the possibility that deployment could be carried out "by one side or the other for its strategic purposes, on the basis of experience already gained." However, he did note that there was not a consensus on Soviet capability thus far.

Finally, he said that there was some uncertainty as to how a moratorium could be adequately verified, "particularly by national means alone." He concluded his remarks by stressing that these "general observations" were not intended to "prejudge" the Administration's position, which was still being studied. 
August 6:

August 19:
Senate debate on the Safeguard ABM system ended with a roll call vote of 49-51. The vote defeated the HartCooper amendment to the authorization for military procurement, thereby approving deployment of the system.

In a comprehensive report on the proposed MIRV moratorium, Chalmers Roberts of the Washington Post, explored the possibility that the Administration was experiencing sharp differences of opinion on the advisability of a joint halt to testing. Based on Defense Department testimony before the House Foreign Affairs Comittee, and letters received by Senator Brooke from various Administration officials, Roberts reported that the main point of difference revolved around the question of "whether the Russians could carry out clandestine MIRV tests which would go undetected by the United States."

The Foreign Affairs Commissions of both chambers of the Supreme Soviet issued reports which approved ratification of the Nuclear Nonproliferation Treaty. Approval by the entire Supreme Soviet, which was to meet in the fall, was required prior to ratification. Foreign Minister Andrei Gromyko commented on the importance of Article VI of the treaty, with regard to the obligations of the signatories to negotiate measures to stop the arms race. Pravda reported that Gromyko had said "The Soviet Government regards this provision of the treaty with all seriousness. It has more than once expressed readiness to hold such negotiations with a view to finding mutually acceptable solutions to this major problem." 
September 22: Following the opening of the U.N. General Assembly on September 16, Secretary of State Rogers and Soviet Foreign Minister Gromyko met in New York for more than three hours to discuss several issues which were of interest to both powers. ACDA Director Smith attended the meeting, along with several other U.S. and Soviet officials. While a Soviet response to the U.S. offer for SALT was not forthcoming at the meeting, Gromyko assured reporters afterward that "the time will come for an answer." Later, State Department spokesman Robert J. McCloskey revealed that Gromyko had told Rogers to expect a Soviet reply "soon," on the time and place for "preliminary talks." Press reports added disclosures from "Soviet sources" in the U.S. that the Soviet Union would seek a meeting in Helsinki by mid-October; State Department officials had indicated that the U.S. position on a meeting site was not inflexible. A second dinner meeting between the two officials was scheduled for September 26.

October 25:

Announcement of the opening of the strategic arms limitation talks was issued in identical statements in Moscow and Washington: "Confirming the agreement reached earlier to enter into negotiation on curbing the strategic armaments race, the Governments of the United States and USSR have agreed that specially designated representatives of the United States and the Soviet Union will meet in Helsinki on November 17, 1969, for preliminary discussions of the questions involved."

In a press conference the same day; Secretary of State Rogers explained that the purpose of the preliminary discussions was to determine how the negotiations would be conducted, e.g., whether to have an agenda and to settle on a permanent site for the negotiations. On this point, he noted that the U.S. preferred Vienna because Helsinki had "some problems of communication and availability of space," but he was not excluding Helsinki as a possible site. While he assured the press that the public would be kept informed "when it's appropriate," as well as the Congress and U.S. allies, he stressed that the sessions themselves would be private.

He said that the talks would not be opened with a summit meeting, and that the Soviet delegation would probably be the same size as the U.S. delegation. 
October 25: (cont.)
He declined to comment on any specific proposals which the United States might offer, or on Soviet attitudes toward particular arms limitation measures. He stated that "the negotiations will include both offensive and defensive strategic weapons," and would not offer any definitions of terms. Questioned on the possibility of a MIRV testing moratorium proposal at the preliminary talks, he noted that "We are not going to exclude any subject from discussion at the preliminary meetings...Our attitude is quite flexible." He did not consider Chinese strategic power relevant to these particular discussions.

In terms of a specific goal of the talks, he hoped that any agreement might leave the two nations in positions where neither had an advantage over the other. Adequate verification of such an agreement would be an important consideration. He characterized the attitudes of both the United States and the Soviet Union as serious and realistic: "We are not talking about détente, or anything else. We are talking about whether it makes sense for the two of us to continue to spend immense amounts of money for the next five, or ten, or 15 years on strategic weapons and end up...in the same relative position." While an agreement could be in the form of a treaty, he said that the U.S. was flexible as to the nature of an agreement.

Rogers also stressed that the talks were "not conditional, in any sense of the word," leaving the impression that the progress of the talks would not depend on an improvement in the general pattern of East-West relations. He warned that while the initiation of SALT tended "slightly to improve the atmosphere...we shouldn't be euphoric about the fact that we are having talks."

On the same day, White House press secretary Ziegler disclosed that Soviet Ambassador Dobrynin had met with President Nixon at the White House on October 20, to notify him that the Soviet Union was willing to enter SALT. At this time, he also had proposed the November 17 starting date, which was accepted by the President. Details concerning the site and announcement were worked out between Dobrynin and Secretary of State Rogers on October 22. Press reports attached some significance 
October 25: (cont.)

October 26:

October 28: to the October 20 meeting, in that it was held on the same day that Soviet-Chinese border talks opened in Peking. It was believed that because of Chinese criticism of what appeared to be an improvement in Soviet attitude toward the U.S., the Soviet Union had withheld its response on SALT until relations with Communist China were more favorable.

According to "informed sources," as reported in the . Washington Post, the United States had photographs of a new Russian bomber of medium range, with a swing-wing, and able to carry air-to-ground missiles. The photographs of the bomber in flight would indicate that Russian development had proceeded further than U.S. development of its new bomber, the advanced manned strategic aircraft (AMSA), which was still in the early planning stages. There was some speculation in the report that the Soviets had purposely allowed U.S. intelligence to detect the bomber in order to gain additional leverage in SALT. It was also reported that during the preliminary preparations for the talks, the question had arisen as to how the bomber had remained undetected for the approximate period of five years it took to be developed to this stage.

The fact that knowledge of the bomber was gained by the use of cameras which would probably be used to monitor an arms control agreement was expected to have some impact on SALT. It was thought that a key question would be whether it would be more advantageous to seek curbs on deployment or to attempt to limit the armaments through curbs on testing.

Following a conference where Republican congressional leaders consulted with the President and adviser Kissinger, Senate Minority Leader Hugh Scott commented on linking SALT with other problems between the United States and the Soviet Union: "You can't dissociate arms limitation from other Soviet-American problems such as Vietnam and the Middle East...Progress in one area is related to progress in another." White House press secretary Ziegler referred to Rogers' press conference remarks on October 25, but added: "These talks cannot take place in a vacuum...The President's feeling is that there is a certain relation between SALT and outstanding political problems." 
$\underline{1969}$

October 29: In closed hearing before the Senate Foreign Relations Committee, Secretary of State Rogers responded to questions on a MIRV testing moratorium. In 11ght. of the planned initiation of the talks, it was Rogers' opinion that it would not be "helpful to have further discussions on MIRV now." To clarify his remarks concerning the relationship between the talks and other issues, Rogers said that the climate of the talks could be affected by international developments.

Earlier that day, Senator Edmund Muskie appeared on a television program, where he urged a unilateral halt of MIRV testing in order to encourage a similar move by the Soviet Union, a gesture which he considered an important first step to the talks in Helsinki. Muskie likened the move to that made by President Kennedy in 1963, when the United States unilaterally suspended nuclear tests in the atmosphere, in an effort to pave the way to the conclusion of a partial test-ban treaty.

October 31:

Soviet newspaper Pravda voiced some criticism of the remarks of Republican congressional leaders, who suggested links between SALT and other issues. Washington correspondent Yuri Barsukov noted that these comments conflicted with those of Rogers, and posed the question: "What is the real position of the Government of the United States on the question of preliminary exchange of opinions in Helsinki: a continuation of the policy of confrontation or discussion without preliminary conditions."

November 3:

The U.S. Air Force announced that it had requested five aircraft companies to submit detailed proposals on the airframe and engine for a new U.S. bomber, the B-1 (formerly AMSA), a move which was partly justified by evidence of Soviet development in the same field. It was explained in the announcement that the preliminary steps did not mark a commitment to production.

In regard to SALT, a New York Times report cited a Pentagon source who claimed that there would be sufficient time to judge the prospects for limitation of bombers. before the plane was tested, or at the most, prior to full-scale production. 
LRS-22

1969

November 7:

State Department spokesman Robert J. McCloskey reaffirmed Secretary Rogers' press conference remarks (see October 25 above) to the effect that there was no "linkage" between SALT and other political questions. McCloskey termed Rogers' statement "administration policy," and added "they [SALT] begin without conditions and we do not attach conditions to their beginning or their development."

November 10: Following a meeting of the National Security Council (with Gerard Smfth, head of the U.S. delegation to SALT attending), it "became known," according to the Washington Post, that the United States would not propose a MIRV testing moratorium at the preliminary negotiations in Helsinki. Rather, it was reported, the United States would seek an understanding on the scope of the talks, e.g., determining what weapons would be included in later, substantive discussions. There was little evidence available concerning the Soviet Union's initial proposals.

Earlier, the Post report discussed further details concerning the Americans position, e.g., that the United States considers the 700 Soviet medium range missiles (MRBMs) targeted on Western Europe as "strategic" weapons, while excluding the 7,000 American nuclear weapons. in Europe on the grounds that they are "tactical" weapons. Moreover, it was recognized that the United States was prepared to accept national means of verification for certain kinds of arms control agreements, although these were not defined.

November 11: Soviet news agency Tass announced the members of the Soviet delegation to SALT in Helsinki. The group would be led by Deputy Foreign Minister Valdimir S. Semyonov, third ranking man in the Foreign Ministry, whose specialty was believed to be concerned with Soviet relations with Central Europe, particularly Germany. The other members of the delegation were listed as Col. Gen. Nikolai V. Ogarkov, first deputy chief of staff, Pyotr S. Pleshakov, Deputy Minister of Radio Industry, Aleksandr. N. Shchukin, academician, Co1. Gen. Nikolai N. Alekseyev, and Georgi M. Korniyenko, head of American desk in the Foreign Ministry. 
November 11: (cont.)

November 11:

November 11:
It was reported in the Washington Post that West Germany was concerned that an agreement between the Soviet Union and the United States might exclude from any limitation the 700 Soviet medium-range missiles aimed at Europe. Reportedly, the U.S. view of the Soviet forces was basically in accord with that of West Germany. According to the report, it was feared in Bonn that consideration of the missile force would fall "somewhere between" the Helsinki agenda and that of the NATO-Warsaw Pact talks on mutual force reductions. In an interview with Der Spiegel, German Defense Minister Helmut Schmidt said: "I would strongly oppose any proposal... which reduced all the conventional armaments of East and West Europe to a very low level, but left everything in the nuclear field the way it is today, including the 700 Soviet MRBMs."

Senator Brooke voiced disappointment at the President's decision not to seek a MIRV testing moratorium while the Helsinki talks were under way, and expressed the hope that the President might reconsider the measure. Brooke said that if MIRV was not given priority at Helsinki, he would call for Senate action on the resolution (see June 17 , above) which urged the President to seek a mutual halt to MIRV testing. Representatives Donald Fraser and Jeffery Cohelan, who were among sponsors of a similar resolution in the House, said that the decision indicated how much influence the military would have during the negotiations.

It was reported in the Baltimore Sun that the United States would not propose a MIRV testing moratorium because of divided opinion on the measure within the Administration. Depending on the resolution of conflicting views on the U.S. position, it was reported, any proposal on the testing moratorium would be delayed, at least until the substantive phase of SALT. Since these talks were expected to begin in January, some observers believed that at that time, MIRV testing would not have proceeded to a point which could warrant deployment. Therefore, a delay until that date was not thought to prejudice the chances for making the proposal. Qthers contended that a primary goal in strategic arms limitation should be the control of the number of delivery vehicles, regardless of the type of warhead. 
LRS-24

November 12: The chairman of the Senate Foreign Relations Subcommittee on International Organization and Disarmament Affairs, Senator Albert Gore, announced that the subcommittee's scheduled briefing on SALT had been cancelled. (ACDA Director Smith had been asked to testify in an executive session of the subcommittee, prior to his departure for Helsinki.) ACDA issued a brief statement: "We understand that the White House is planning to handle the matter of briefing Congress on our approach to the Helsinki talks." There was no immediate comment from the White House, although press reports indicated that the instructions barring Smith's appearance had probably come from the President's adviser on National Security Affairs, Henry Kissinger.

November 13:

In a speech on the Senate floor, Senator Muskie continued to emphasize the need for a moratorium on MIRV testing "before it is too late." Moved by the Administration decision to defer such a proposal until the beginning of substantive talks, Muskie said: "The issue is not whether an agreement on MIRV is part of a larger agreement between the United States and Russia on strategic arms control. The question is whether the larger agreement is possible without stopping deployment of multiple warhead missiles."

November 13: In an address before a group of retired diplomatic and consular officers, Secretary of State Rogers described the general approach of the United States to SALT without mentioning any specific proposals. He recognized that both the Soviet Union and the United States were capable of destroying each other, and offered that the risks involved in seeking an arms control agreement seemed "less dangerous than the risks of open-ended arms competition." He also mentioned the military, political, and economic disadvantages of the arms race. Commenting on the timing of the start of talks, he noted that they were being held while the two powers were in approximately the same strategic position. The fact that there was little chance of one gaining an advantage over the other gave rise to hope for a meaningful outcome to the discussions. Another hopeful aspect of SALT was one he labelled "mutuality of interest," in that should the talks be successful, they "may accomplish an historic 
November 13: (cont.)

November 13:

November 14: breakthrough in the pattern of confrontation that has characterized the postwar world." He added that "developments in other areas are bound to have an impact on these discussions."

He cited three objectives of the United States as it entered SALT: (1) "to enhance international security by maintaining a stable U.S.-Soviet strategic relationship through limitations on the deployment of strategic armaments. (2) to halt the upward spiral of strategic arms and avoid the tensions, uncertainties, and costs of an unrestrained continuation of the strategic arms race. (3) to reduce the risk of an outbreak of nuclear war through a dialogue about issues arising from the strategic situation."

Soviet comments on SALT appeared in an article by N. Nikolayev, writing in the foreign affairs weekly Novoye Vremya. Nikolayev said that the Soviet Union was entering the talks "with determination to achieve positive results, to put a stop to the arms race of constructing ever more destructive means of attack and counterattack." He expressed hope that the U.S. delegation would have "plenary powers...that will make it possible to get positive results from these meetings and the following difficult and, perhaps, lengthy negotiations." He also mentioned a speech by Soviet President Podgorny at a November 6 rally commemorating the 52nd anniversary of the Bolshevik revolution. Podgorny had expressed hope for success in the talks, and stressed the urgency of restraining the arms race.

Head of the U.S. SALT delegation Smith attended a meeting of the North Atlantic Council in Brussels, where he briefed the Allies on the forthcoming negotiations. 
November 17:
The opening of the strategic arms limitation talks took place in the Finnish state banquet hall in Helsinki, in a public ceremony attended by the Soviet and American delegations and Finnish dignitaries. The head of each delegation spoke briefly. First to address the gathering was Soviet representative Semyonov, who said that the goal of the talks--"curbing the strategic arms race, limitation, and subsequent reduction of such arms"-would meet the vital interests of both countries, as we11 as those of other nations. He noted that "given genuine desire on both sides to seek mutually acceptable agreement without prejudice to the security of our states and all other countries, it is possible...to bring about reasonable solutions." He expressed the hope that the Helsinki discussions would "develop in a constructive manner and create the necessary foundation for further negotiations." American representative Smith read a letter from President Nixon, who also mentioned the goal of "mutually acceptable limitation and eventual reduction of our strategic arsenals." He added that "we seek no unilateral advantage. Nor do we seek arrangements which could be prejudicial to the interests of third parties." He also noted that "wars...can arise not simply from the existence of arms but from clashing interests or the ambitious pursuit of unilateral interests. That is why we seek progress toward the solution of the dangerous political issues of our day."

Following the ceremony, the two delegations retired to an adjacent room and met for approximately 30 minutes to work out some procedural points. The first full working session of the talks was scheduled for the next day at the American Embassy. (It was planned that the locations of the meeting would alternate between the Soviet and American Embassies.) Press reports described the general attitude as one of utmost secrecy and one which did not expect an immediate agreement from the talks.

November 19: A closed briefing on SALT by Administration officials was held for the members of the Disarmament Subcommittee of the Senate Foreign Relations Committee. Three officials, ACDA Deputy Director Philip Farley, General 
November 19: (cont.)

November 20:

November 23:
Counsel William Hancock, and Helmut Sonnenfeldt, Soviet and disarmament expert on the National Security Council, took part in the session. Following the meeting, Senator Clifford Case said "The possibility of interim agreements, such as stopping the MIRV tests while the talks are going on, is not ruled out." The following day, Subcommittee chairman Gore commented favorably on the briefing, noting that he was "pleased with the latitude available for exploration" in the Helsinki talks. (On November 18, Presidential Assistant Kissinger had conducted a similar meeting for Senate leaders of both parties.)

The second SALT meeting was held at the Soviet Embassy, and according to "conference sources," as reported by the Washington Post, the United States presented its opening position to the Soviet Union. It was believed that the U.S. position had taken the form of suggestions for exact topics of future, substantive discussions, as opposed to specific arms limitation proposals. The Soviets requested that the next meeting be postponed until November 24, presumably to take time to consider the American position and to formulate an appropriate response. (The first neeting, held on November 18, had been devoted to "statements of principles and discussion of procedures," according to a New York Times report.)

The Soviets also made public for the first time a list of 18 advisers accompanying their delegation. The group included six military officers, believed by Soviet sources to be missile experts. The 19 -member U.S. staff included four military officers and two civilians from the Department of Defense.

Soviet newspaper Pravda offered its comments on SALT, the first since the opening of the Helsinki discussions. One article described the atmosphere in Helsinki as "on the whole favorable for a businesslike discussion." But it noted that there might be some difficulties concerning the U.S. negotiating position primarily because of the attitudes of the NATO allies. A London Daily Telegraph report was cited, which appealed to 
November 23: (cont.)

November 24:

November 27: the U.S. to exact concessions from the Soviet Union on certain international problems. The Pravda article also mentioned that certain "opponents of detente" in the NATO countries, including West Germany, were "alarmed" over the bilateral arms talks. In a separate commentary, Soviet writer Igor Belyayev preferred to reserve judgment on the outcome of the talks. He did point out that agreement in this field would "undoubtedly" improve Soviet-American relations.

Soviet and American negotiators met for two hours in the longest working session of SALT thus far. It was reported that the opening position of the Soviet Union had been presented at the meeting, held in the American Embassy. Press reports did not venture to speculate on the nature of the Soviet position, although judging from the general atmosphere, there were indications that no fundamental differences had developed. It was reported in the Washington Post that the discussions had been made in general terms, with the head of each delegation reading "talking papers," prepared prior to the opening of the conference, with some exchange of questions and answers. According to the New York Times, representatives of both countries had described the progress of the talks with such terms as "steady" and "concrete."

In a television interview, Secretary of State Rogers offered the first public assessment of SALT by a U.S. official since the opening of the discussions. As a result of conversations with U.S. representatives in Helsinki, he said, "the manner of dialogue is the best of any discussions they have had with the Soviet Union," and added that "we were very encouraged by the general atmosphere." Rogers was also questioned about the projected completion of MIRV testing (May or Jume 1970), and the impact it would have on SALT. Although he agreed that MIRV deployment might make it more difficult to enforce an arms control agreement, he stated that "it is just one of those facts of life we will have to face up to." He doubted that agreement could be reached prior to May or June. He discouraged the view that there was 'something magic" about reaching agreement prior to 
November 27: (cont.)

November 28: completion date, claiming that "you don't necessarily have to finish the tests in order to deploy." He noted that there was uncertainty on both sides as to the progress of the respective MIRV programs, and said that if the United States proposed a testing moratorium "too aggressively," it would only make the Soviets "naturally suspicious" that the U.S. had completed enough tests.

After the fifth working session of SALT, it was agreed that there would be a three-day recess in the negotiations. Considering the large amount of complex information which had probably been exchanged, it was the view of press reports that during the recess, each side would send the information gained from the talks back to the respective capitals for analysis and consultation. There were also indications that this meeting may have marked the end of a first round in the preliminary discussions, consisting of exchanges based primarily on basic nuclear policy and definition of the term "strategic arms." It was believed that subsequent sessions would be concerned with settling on an agenda, and a date and location for the substantive talks.

A New York Times reporter cited "Soviet sources" who were in agreement with Rogers' statement that the talks were the "best of any discussions" which the United States has had with the Soviet Union. A Washington Star report indicated that the United States had a fairly good idea of Soviet aims in the talks, although Soviet attitudes toward a MIRV testing moratorium remained unclear. It was the view of the report that President Nixon might propose this measure at the beginning of the substantive negotiations. It was reported that the Soviets had displayed some unofficial interest, but the matter was still undergoing Kremlin review.

After six meetings of preliminary SALT, the New York Times reported that the negotiators had agreed on basic topics to be explored in future talks. According to descriptions by "Administration officials," the substantive talks would cover offensive weapons, defensive weapons such as the ABM, the relationship between offensive and defensive weapons, and means of verifying an agreement. Although the areas were rather broad and 
LRS -30

1969

December 4:

(cont.)

obvious, it was pointed out that agreement on this much was still something of an achievement. One disarmament official characterized the negotiations as "businesslike" and "non-propagandistic," a manner which contrasted with past arms control discussions between the two countries. He also offered the view that by "defining areas of mutual interest... [the negotiators were] laying the groundwork for substantive negotiations." That the two sides had agreed to discuss the relationship between offensive and defensive weapons was reported to be an "implied recognition" that the MIRV issue would have to be considered. "A prevalent Administration view on the MIRV testing moratorium had linked limitations on the multiple warhead with restraints on defensive systems as well.) The report also mentioned "doubts in some congressional circles" that the negotiations might become too involved in the technical difficulties of verification, a shift which might detract from the overall political desirability of arms control, and thus impede the progress of SALT.

In terins of developments within the U.S. Administration, the report noted that apparently there was some disagreement as to what form an eventual agreement should take. It was believed that the Joint Chiefs of Staff were in favor of a formal treaty, an agreement which might be more difficult to negotiate, and thus more limited in scope. On the other hand, the State Department and ACDA were thought to favor informal agreements, by which limitations could be carried out by "mutual example" or "para11elism."

December 5: The third week of SALT ended with a 90-minute meeting, followed by a two-hour luncheon hosted by the U.S.

delegation. Ten members from each side attended. Press reports indicated that the cordial atmosphere which had characterized the discussions remained unchanged. The previous day, Secretary of State Rogers met with NATO officials in Brussels where he predicted that the preliminary talks would probably last another two weeks, perhaps with a month recess prior to the opening of substantive talks. Speculation was also advanced over the negotiation of a possible site for the second round of talks. Washington was said to favor Vienna, where U.S. facilities 
December 5:

(cont.)

December 6: were better equipped than those in Helsinki, the site preferred by the Soviet Union. It was believed that the Soviets opposed Vienna, partly because Austria had criticized the Soviet invasion of Czechoslovakia in August 1968, and therefore was not neutral according to Soviet standards. It was also hinted that the talks might alternate between Moscow and Washington.

The Washington Post reported that the United States had adopted a more flexible position concerning verification of an arms control agreement, by placing more emphasis on national means of inspection rather than on-site inspection. To account for the shift in policy, the report noted that detection by the reconnaissance satellites which would be used in such a system had greatly improved. Thus, the increased efficiency of these and other intelligence devices had minimized the risks of evasion of an arms control agreement. And in the view of U.S. policymakers, it was reported, the value of an arms control agreement verified by national means would outweigh these risks. It was also stated that nine different options for arms control proposals, which remained secret, had been developed by the United States. As a result of less concern for on-site inspection, a requirement which had been a substantial stumbling block in previous negotiations, it was expected that these positions would contribute a great deal to the prospects for success in SALT.

It was stressed, however, that according to informed sources, the possibility of an on-site inspection proposal by the U.S. had not been eliminated entirely, for certain weapons systems.

For instance, satellites might monitor an agreement on a fixed number of nuclear missile submarines, but submarine construction yards would remain open for on-site inspection. As an alternative to this plan, it was suggested by the report that roofs from construction sheds might be removed to permit aerial inspection. 
December 6:

December 8:
In an address to the Belgo-American Association in Brussels, Secretary of State Rogers said that a U.S. goal in SALT was "to put an end to the competitive accumulation of ever more sophisticated weapons systems which can no longer add significantly to the security of either side...[and] to limit, and if possible reduce on both sides, inventories of strategic weapons." He described the atmosphere at Helsinki as "businesslike and without polemics." He pledged full consultation with the Atlantic allies, and added that "we will take no steps which would weaken their security."

In a press conference, President Nixon offered his first assessment of SALT since the beginning of the talks. He called the progress of the negotiations "encouraging," and said that "because both sides are presenting positions in a very serious way and are not trying to make propaganda out of their positions...there is a chance for an agreement." He cautioned that it would take some time to reach agreement, since in these particular negotiations, the "basic security" of the two sides is involved and "both must bargain hard."

The President was questioned on why the U.S. delegation had cancelled a meeting scheduled for that day. He said that the postponement was "only for the purpose of developing positions in a proper way," and that it had no "long-range significance." A New York Times report cited a "well-informed source," who had disclosed some details surrounding the postponement. It was reported that the delay had been agreed upon by the two top negotiators, Smith and Semyonov, in order to allow more time for discussions between the delegations at the "working level." Apparently the general pattern of the negotiations had been such that informal meetings had been held between the experts from each side to work out details and to reach certain "understandings" before the principal negotiators met. Since the preliminary talks were nearing an end, it was believed that a great number of minor points would have to be settled before positions were submitted to the negotiators for a final decision. 
December 16:

December 22:
The U.N. General Assembly adopted Resolution 2602 A (XXIV) which called on the United States and the Soviet Union to halt further testing and deployment of new offensive and defensive strategic nuclear weapons systems, "as an urgent preliminary measure." (A move to amend the resolution had been defeated in the First Committee on December 9. Rather than a moratorium, the proposed version was an appeal to the two nations "to refrain from any action which might be prejudicial to the achievement of" the aims of SALT. Both the United States and the Soviet Union had supported the amendment, on the grounds that the original wording might have a negative effect on SALT or that it was a "hasty interim measure, that might fail the test of time.") The approving vote for the resolution as it was first introduced, was 82-0, with 37 abstentions.

Following the final session of preliminary SALT, a joint communique was issued which announced that the discussions would be resumed on April 16, 1970, in Vienna, to be moved to Helsinki "at a later time." (A New York Times account stated that agreement on the site was the result of a compromise. Apparently the U.S. had hoped for resumption of the talks in January or February, but the Soviets asked for a later date, to allow for necessary consultations in Moscow. The Soviets agreed on the site in exchange for U.S. consent to the mid-April starting date.)

The communique described the preliminary exchange as "useful to both sides," and that "as a result...each side is able better to understand the view of the other." Concerning the areas to be discussed, it said only that "an understanding was reached on the general range of questions which will be the subject of further U.S.Soviet exchanges."

The head of each delegation made a closing statement after the final meeting. U.S. Representative Smith said that the talks had enabled each government to have a "better understanding of each other's views," and emphasized the preliminary nature of the Helsinki talks: "I take sober satisfaction that our preliminary talks have led to an understanding...to resume negotiations... The main task is, of course, still ahead of us. But we have made a 
December 22: first step in the right direction, and this in itself (cont.) is an achievement." He also expressed appreciation to the Soviet delegation for the "businesslike manner" in which they had participated in the talks. Soviet delegate Semyonov said that the USSR "consistently and steadfastly" favored "peaceful coexistence of states, regardless of their social system; peace and security; and general and complete disarmament." He added that it was these principles which had guided the Soviet Union in the preliminary talks. He also said that curbing the arms race was in the "vital interests" of both the Soviet Union and the U.S., as well as other countries, and that "we will strive at the forthcoming talks to achieve a mutually acceptable agreement on this problem."

The Washington Post stated "with authority" that the wording of the communique indicated that each side had accepted the idea of mutual deterrence. Accordingly, it appeared that the problem at hand was to devise a method of maintaining the balance of power which resulted from the rough parity between the two countries. Moreover, there was agreement on the necessity for an adequately verified agreement, although details were deferred for later discussion. In the meantime, the negotiators agreed that neither side should do anything to upset the roughly equal standing of the two countries. Reportedly, the U.S. was most concerned about the Soviet SS-9, while the Soviets expressed concern over the U.S. submarine system with nuclear missiles. According to the Post report, Soviet explanations of the SS-9, "left the impression" that they were intended to destroy U.S. ICBMs. It was also reported that the discussions were frank concerning the targetting of each country, and that the Soviets stressed that they had more targets to cover in the U.S., than vice versa. This factor was expected to come into play during consideration of ways to maintain the strategic balance. In addition, it was asserted in the Post that the Soviet medium and intermediate range missiles aimed at Western Europe had been discussed "with differing views on their importance in relation to the balance of power." Moreover, because of the wording of the communique concerning the future agenda, the report noted, these missiles would come within the scope of the April talks. 
LRS-35

1969

December 22:

(cont.)

Press reports also commented on how the agreement to begin the substantive phase of SALT would probably affect other East-West dialogues, e.g., talks with the West Germans in Moscow, and imminent talks of the West Germans with Poland and East Germany. The Post report expected that agreement would aid efforts to reduce conventional arms in Central Europe. According to the New York Times, the Soviets had relied heavily on the election of Social Democrat Willy Brandt as Chancellor for a West German initiative in East Europe. It was believed that Soviet participation in SALT was a move made in an effort to relieve pressure in one area so that the Soviet Union could concentrate on its relations with West Germany. The Times report pointed out that Soviet Ambassador Dobrynin had notified President Nixon of Soviet willingness to enter SALT on the day Brandt was installed as Chancellor (October 20).

December 29: Chief U.S. negotiator Smith met with President Nixon to report on the progress of SALT. At a press conference afterward, Smith said that the "prospect and hope is brighter than it has been in the past," but he cautioned against striking an "overly optimistic note," and said that "we are certainly a long way from home." He affirmed that the Helsinki talks resulted in agreement on a "work program," rather than a formal agenda with listings according to priority; the work program would not be published. As to the nature of an agreement, he said that there might be a "first agreement" concluded, with more comprehensive measures to follow. But he did not rule out the possibility of. a single comprehensive agreement in the beginning. He declined to comment on whether a MIRV testing moratorium had been discussed in Helsinki, but did not deny that it would be taken into consideration as the U.S. negotiating position for the April talks was developed. Concerning a unilateral MIRV testing halt on the part of the United States and its effects on SALT, Smith said that in general he did not consider unilateral moves a "very sensible way to approach this type of complicated problem," but added "I would like to reserve judgment on that." In conclusion, he said that no specific weapons system had been ruled out from further discussion as a result of the meetings in Helsinki. 
December 29:

The Chairman of the Senate Armed Services Committee, Senator John Stennis, announced that a seven-member subcommittee had been created in order to follow the progress of SALT. The group would be chaired by Senator Henry M. Jackson. Stennis said that he considered it "essential" for the committee to be kept informed on the talks so that if an agreement were reached, the committee would be "in a position to assess the implications of the agreement on this nation's military posture and the balance of strategic power." He stated that hearings would be held "at appropriate intervals," and emphasized the committee's interest in "the all-important question of adequate safeguards and verification of any agreement."

December 31:

The New York Times reported that Administration officials expected the Vienna talks to deal more with defining terms rather than with specific proposals. Apparently the Helsinki talks were so general, that even if a specific proposal were offered at Vienna, considerable time would be spent in defining terms and concepts. For instance, strategic bombers are included on the work program for Vienna, supposedly at Russian insistence. While the U.S. places its B-52's in this classification, it does not consider the bombers on U.S. aircraft carriers in the Mediterranean or the tactical fighter-bombers in West Germany under this category. Similar Soviet fighter bombers cannot reach the United States and therefore, would not come under this classification in the Soviet view. However, because of U.S. pledges to its NATO allies, it was believed that in any limitation on strategic bombers, the U.S. would seek to include Soviet medium range bombers aimed at Western Europe.

It was also reported that there was some disagreement within the Administration concerning the U.S. approach in Vienna. Reportedly, ACDA officials favored tabling a proposal at the outset, while Pentagon and Department of State officials believed that to offer a proposal too soon might only harden positions on both sides. Several options for U.S. proposals were discussed in the news report. One was quite similar to the approach taken by the Johnson Administration, which favored a proposal to freeze the number of 1 and and sea-based ICBMs, with no ban on qualitative improvements, e.g., MIRV. (This would 
December 31: place the Soviet Union at an advantage in terms of land(cont.) based ICBMs, but the U.S. at an advantage with its Polaris-type missiles). Sufficient ABMs would be permitted as defense against a third power, but not enough to prevent a retaliatory blow from one superpower against the other. The second option would do away with all land-based missiles with fixed numbers of mobile missiles on 1 and and sea. In this way, the locations of strategic forces could not be fixed, and the threat of a first-strike could be lessened or avoided. Bombers and ABMs would also be included in the limitation. The third approach would attempt a limit on total payload of each nation's strategic forces, leaving the kind of missiles optional. This approach would involve agreement on how to measure payload on any given missiles, perhaps by volume. 
LRS -38

1970

January 1:

According to informed sources, as reported in the Washington

Post, a principal concern of the Soviet Union at the preliminary Helsinki talks had been U.S. plans for its strategic bomber program, particularly the $\mathrm{FB}-111$ and AMSA. (The Air Force intended to buy 77 FB-111's, a plane which can carry enough fuel to reach Russia, while the AMSA was still in the early planning stages.) The Washington Post noted that the Russian Tallinn defense line across the northeastern approaches to Russia was anti-bomber, rather than anti-ballistic missiles, a system wh1ch was believed to be 1neffective against AMSA. Presumably, the Russians might seek restraint on AMSA in order to avoid a costly revision (some had estimated $\$ 14$ billion) of the Tallinn system. The U.S. was considered ahead of the Russians in bomber development, in spite of the recent tests of their new medium range bomber (see October 26, above). Soviet development efforts were thought to be directed more toward the SS-9. Reportedly, Soviet queries about the bombers had been posed in response to U.S. concern over the Soviet SS-9. There was some speculation that a tradeoff of AMSA for the SS-9 might be a potential arrangement in future arms control negotiations. However, it was also reported that scant knowledge of Soviet intentions of the SS-9 was gained by the U.S. at Helsinki. Moreover, informed sources had disclosed that the Soviets had shown little interest in a MIRV testing moratorium, perhaps in an effort to catch up with U.S. development before negotiating

January 7:

Senator Albert Gore, Chairman of the Disarmament Subcommittee of the Senate Foreign Relations Committee announced that officials would be called on later in the month for briefings on the progress of SALT. Gore described the briefings as "part of a continuing interest" of the subcommittee in the talks. He added that he was considering a "thorough review of the ABM problem," with stress on whether expansion of the system might impede the progress of the talks. 
January 8:

January 13:

January 29:
Secretary of Defense Laird said in a press conference that the United States might have to consider building a new strategic bomber and a long-range submarine missile system because of the rapid build-up in the Soviet SS-9's. In an article in Red Star, Soviet news agency Tass said that his statement "shows that despite Washington's official assurances that it is in favor of limiting the nuclear missile arms race, the United States continues building up its potential of offensive weapons." Another article in Red Star criticized Laird's reference to a possible expansion of Safeguard. In spite of Soviet efforts to curb the arms race, the article said, members of the U.S. militaryindustrial complex "are doing everything they can to prevent anything being done to limit the arms race." The article also noted concern in Washington that such plans would have a "negative influence" on SALT. Western observers viewed these references as a reflection of similar attitudes on the part of the Soviets, especially since the only significant coments thus far on Laird's proposals appeared in the Soviet armed forces newspaper.

In a Moscow press conference, the head of the press department of the Soviet Foreign Ministry, Leonid M. Zamyatin, said that while American statements on possible new weapons systems did not help SALT, the Soviet Union was confident that the Vienna talks "will be in the same spirit that marked Helsinki." It was also announced that the Soviet Union had taken a "favorable attitude" toward U.S. participation in a proposed al1-European security conference.

The Washington Post reported that there had been a secret briefing which chief U.S. negotiator Smith conducted for the Senate leadership on January 26. 
January 30:

February 1:

In a news conference, President Nixon announced that as a result of a National Security Council review, he had decided to proceed with both the first and second phase of the ABM system. He said that Defense Secretary Laird would announce the details in about 30 days. He said that this decision involved area defense, (rather than missile defense, the purpose of the first phase), and described it as "absolutely essential...against any minor power...like Communist China." He pointed out that within ten years, China could have a "significant nuclear capability," and that it would be important to have some defense against nuclear blackmail, a potential threat either to the United States or U.S. allies in the Pacific such as the Philippines or Japan.

In a New York Times report dated January 29, the decision was described by military and diplomatic sources as a move to "increase pressure" on Soviet SALT negotiators to reach early agreement on limiting strategic weapons. However, arms control officials were thought to have raised objections to starting an area defense at this time on the grounds that the limited system could be interpreted as the beginning of a broader national defense system, in order to thwart a large-scale Soviet attack. Thus, the Soviets might respond with a build-up in its offensive systems, which the negotiators are seeking to limit through SALT. As a result of these considerations, President Nixon reportedly had ordered further review of the system before the expansion proposal was finalized.

It was reported in the Washington Post that the United States had not settled on the kind of proposal it would make when SALT reopened in Vienna. Supposedly it had been agreed by both nations, prior to the Helsinki discussions, that no proposals would be made at this stage, so that each side could devote its energies more toward learning about the other's thinking on the arms race. 
February 1: (cont.)
Apparently the United States did not receive a satisfactory explanation regarding the purpose of the Soviet SS-9, an uncertainty which was expected to have some impact on final U.S. policy decisions.

At this time, the Soviet Union had deployed or was deploying 300 SS-9s, with a total of 400 expected by the fall if the current rate was maintained. The most current theory, regarding Soviet intentions with its SS -9 , centered on the possibility that the Soviet force could be used in a move of nuclear blackmail in an international crisis, posing a threat that U.S. retaliatory forces could be eliminated. Response to this argument has emphasized that in this case, the U.S. could still rely on its bombers and Polaris submarines; the latter were considered invulnerable since they are sea-based, and adequate to strike a retaliatory blow. On the other hand, there was some skepticism about the ability of U.S. bombers to penetrate Soviet defenses, and doubt as to how long the U.S. Polaris would remain invulnerable. Moreover, it appeared that the Soviet view of its SS -9 program was based on the assumption that the system could survive a U.S. attack.

In terms of a limitations proposal, the thinking at this time was reported to favor a simple limitation on the number of ICBM's each side could deploy, an arrangement to be verified by "national means of detection." An ABM limitation would be included, with only enough of a force to deter an attack by a lesser third power.

It was believed that unless there was some prospect for agreement by the summer, there would be some pressure on the President to seek improvements in U.S. forces, e.g., a ULMS or underwater long-range missile system. It was thought that some advocated a shift of all U.S. forces to sea-based systems, plus aircraft, on the grounds that U.S. land-based ICBMs would soon be obsolete. Such a move was regarded as a play for time for arms control efforts to meet with some success. However, it was also reported that some arms control advocates were hoping that the President would be obligated to take certain risks in SALT, because of the financial considerations 
February 1: (cont.)

February 2:

February 6: associated with new weapons systems. Nevertheless, it was not thought the cost factor had played a prominent role in the Presidential discussions to date on the U.S. course of action if there should prove to be no SALT agreement.

The Senate Disarmament Subcomittee held the first of a series of hearings aimed at exploring the $A B M$, particularly in relation to SALT. U.S. negotiator Smith spoke to the committee in the closed briefing, and commented on the Administration's plans for the April talks. Chairman Gore described Smith's presentation as helpful and candid, but added that proceeding with the ABM and MIRV deployment "could not possibly be helpful" to arms control efforts.

The same day, Congressional reactions to the President's budget were expressed. Senator Mansfield said that while the Executive was requesting less for defense than the previous year, the figure still amounted to more than Congress had appropriated. He warned that the budget contained "seed" money for military systems "that will cost tens of billions in the future years if the initial commitment is made this year." Senate Minority Whip Robert Griffin expressed some apprehension about the budget's $\$ 1.5$ billion request to proceed with phase 2 of the ABM, but added he was "waiting for the justification."

Former U.S. Ambassador to Moscow George F. Kennan testified before the Senate Foreign Relations Committee. Kennan said that because of political and economic reasons, there was reason to believe that the Soviets were genuinely interested in curbing the arms race. It was his opinion that the U.S. position should be one which expresses a willingness "to stabilize the race if they are willing to stabilize." Expansion of the ABM, he said, might cause Soviet uncertainties about U.S. strategic intentions, and might appear to be a delaying tactic "to get some technical edge." Kennan also contended that the dangers of displaying some unilateral restraint were "minimal," when compared with the risks of an escalating arms race. 
February 10: A closed hearing on SALT was held by the Senate Armed Services Subcomittee chaired by Senator Jackson to hear testimony from Gerard Smith. Although Smith's testimony was not made public, Jackson stated prior to the hearing that the United States should "remain within lead-time reach of corrective measures," in case an arms control agreement should be "abrogated." The remark was interpreted as an expression of Jackson's opposition to a halt in both the MIRV and ABM testing programs.

February 18:

In a detailed message to Congress on U.S. foreign policy, President Nixon discussed the U.S. approach to SALT. He reported the formation of the Verification Panel, to explore the means to inspect a variety of arms control agreements. The findings of the Panel provided "building blocks" for analyzing various kinds of limitations, which were listed in three general categories: (1) limitation of offensive forces, by placing a ceiling on the number, with no curb on qualitative improvements; (2) limitations on numbers and capabilities of missiles, including MIRVs (with consideration of more complicated inspection provisions); and (3) reduction in offensive forces, without qualitative limitation, an arrangement based on the theory that a reduced level of weapons would reduce the risk of technological surprise. Each of these possible proposals was considered in relation to various levels of ABMs.

Noting that this "building block" approach would enhance U.S. flexibility in the talks, he pointed out that the Soviets had welcomed this attitude in the Helsinki discussions. He expected that the Vienna talks would move from a discussion of "basic principles and objectives" to "more specific positions." The United States would enter the talks with a "well-developed body of technical analysis and evaluations, which is being continuously expanded and improved by the Verification Panel and the NSC [National Security Council] process." He also reported that detailed consultations with U.S. allies, specifically NATO and Japan, had been held in July and November. 
February 18: Nixon also commented on the Soviet threat, stating that the (cont.)

"present build-up of strategic forces, together with what we know about their development and test programs, raises serious questions about where they are headed and the potential threats we and our allies face." (Nixon cited comparative figures on projected U.S. and Soviet operational missiles for the end of 1970: ICBM's for the U.S., 1,054 and for the Soviet Union, 1,290; submarine launched missiles for the U.S. numbered 656, and for the Soviet Union, 300.) As in previous statements about U.S. strategic policy, he used the term "sufficiency" to characterize the U.S. goals. He added that the U.S. strategic posture was designed "to deny other countries the ability to impose their will on the United States and its allies under the weight of strategic military superiority."

February 20: In his annual posture statement before a joint meeting of the Senate Armed Services Committee and the Defense Appropriations Subcommittee, Defense Secretary Laird said that the President's decision to proceed with phase 2 of Safeguard, would "in the long run, enhance the prospects for the success of SALT because, in the short run, it allows us to exercise greater restraint in matching a continued Soviet buildup of offensive systems with actions involving our own offensive systems." He also noted that it was possible for an arms control agreement to include some form of missile defense, and that the expanded $A B M$ would "not preclude an agreement on low ABM levels." Regarding Communist China, he said it was necessary to cope with this threat "regardless of SALT," since the Soviets exercised no control over the actions of that country. Thus, he described the ABM expansion as "essential to preserve our capability to deter Chinese nuclear aggression against our Asian allies without jeopardizing the U.S. civilian population." He added that the system could be modified as the threat changed, as a result of either arms limitation agreements or unilateral actions by the Soviets or Chinese. 
February 20: (cont.)
In additional testimony on February 24, he explained the details of the President's decision. The proposal called for construction of a missile site to defend Whiteman AFB, Missouri, and preliminary work for sites in Washington, D.C., four general areas throughout the country, and Warren AFB in Wyoming. It was reported in the New York Times that the Department of Defense originally had proposed to the President construction of an additional site in Washington state, but this was rejected, possibly because of arms control considerations. The report added that Soviet negotiators in Helsinki had expressed concern that the ABM system might be expanded into a heavy defense of cities against a Soviet attack. Some officials were thought to believe that such concern would give U.S. negotiators more leverage in SALT, while others contended that to go "too far" with the second phase would convince the Soviets of a U.S. intention to develop a heavy defense, despite public assertions to the contrary.

Director of Defense Research and Engineering Foster said in his testimony that the Soviet Union had over 275 SS-9's in place or going in place, compared with 225 the previous year. The smaller SS-11's (equivalent of the U.S.

Minuteman, with a warhead of about one megaton) numbered more than 800 , as compared with more than 700 the previous year. Despite continued Soviet testing of multiple warheads, Foster said, there was little indication that the Soviets had acquired "the flexibility necessary to target each warhead against a different Minuteman silo."

In terms of total ICBM launchers, Laird said the Soviets had 1,060 operational, with an additional 200 expected by mid-1970. Laird also said that "the accuracy of the SS-9 with a single large warhead is considered sufficient to destroy a MINUTEMAN in its silo," and that this accuracy could be improved. Moreover he noted that there was agreement within the intelligence community that the "Soviets are likely to develop MIRVs... in the next few years." Concerning the Soviet ABM, he said that a number of complexes around Moscow seemed to have been brought to "an operational status," within the past year. 
February 20: (cont.)

February 23:

March 5:
After the hearing, Senator John Pastore, a key supporter of the 1969 Safeguard proposal, reaffirmed his statement of the previous day that defense efforts should be aimed at completion and perfection of the two authorized ABM sites before the system was expanded. Commentirg on the Soviet threat, he said that "we have sufficient time to develop the two stations and then decide" on an appropriate response. For the most part, however, Congressional comment was not immediately forthcoming.

In a Pravda article to commemorate Soviet Armed Forces Day, Defense Minister Andrei Grechko offered a favorable evaluation of the Soviet ABM system: "We possess weapons capable of reliably hitting enemy aircraft and missiles irrespective of height or speed of their flight, at great distances from the defended targets." Some significance was attached to the statement since it was the first official comment on the Soviet ABM program since 1967, when Grechko remarked on the ABM effectiveness with a lesser degree of enthusiasm. It was thought by Western observers that the comment might have been directed toward the United States, perhaps as a bargaining move for resumption of SALT on April 16. Additional speculation centered around the possibility that the article may have marked a move by the Soviet military to justify further expansion of its ABM program. According to U.S. officials, approximately 70 anti-missile launchers had been deployed around Moscow.

At the Washington ceremony which marked entry into force of the NPT, President Nixon said that "the next milestone we the NPT, President Nill be the limitation of nuclear weapons," and, referring to SALT, he voiced the hope that the "climate for progress in those talks will be good." In a corresponding ceremony in Moscow, Soviet Premier Kosygin said that his government "attached great importance" to the talks with the United States and that the Soviets were "making very serious preparations" for the April sessions. The outcome of SALT, he added, "will depend... on the goodwill of both sides." 
Secretary of the Air Force Robert Seamans, accompanied by Air Force Chief of Staff General John Ryan, testified before the Senate Armed Services Committee, where he disclosed that the U.S. would proceed with deployment of MIRV in July, after completion of a 22-month testing program. It was expected that ten to twenty of the new Minutemen 3 missiles would be deployed during the year; this number was termed "minimum," because of budgetary considerations. The missile would have a range of 7900 miles and would carry three warheads, each with a payload of $170-200$ kilotons. According to Ryan, the warheads would have the "potential of attacking different targets with its reentry system 'footprint,'" and it would carry necessary penetration aids.

The decision to proceed with the scheduled deployment apparently had been based on the fact that no SALT agreement was imminent and that the Soviet Union had not exercised any restraint in its own weapons programs during the talks. The combination of MIRV and phase two of Safeguard was expected to provide an effective deterrent "for a considerable time." Ryan stated that the pace of Soviet deployment and research efforts indicated "clearly that they are seeking military superiority, particularly strategic nuclear superiority." He said there was no evidence that the Soviets had tested a hard-target MIRV, but, added, "they have the technology to develop such a MIRV, and we believe they will do so."

Administration sources stated that while the deployment date had been known for some time, no proposals had been made to the President to delay the schedule. Thus, it was believed that any SALT agreement would probably be based on quantitative rather than qualitative curbs. On the basis of this assertion, MIRV was considered neither a destabilizing factor in the arms race, nor a stumbling block to an arms control agreement, as its critics had contended. 
March 10: (cont.)

March 12:
On the same day, in a speech on the Senate floor, Senator Brooke said there was "no military justification for deployment...on the timetable originally planned." He pointed out that the defenses which MIRV was designed to penetrate "do not exist and could not be installed in the immediate future," and added that MIRV deployment would not add to U.S. security and would only complicate arms control efforts. He called for prompt Senate action on the resolution he introduced the previous June, with 43 co-sponsors, and urged the President to postpone "this unwise deployment."

In a Pentagon briefing, spokesman Jerry Friedheim told newsmen that "everything is negotiable in SALT." He asserted that U.S. MIRVs did not have the capability of attacking Soviet hardened silos, nor did the U.S. Intend to develop such a capability. (The term "hard target," he explained, referred to factories and bridges, rather than missile sites.) Friedheim stated that the Soviets were "very close" to attaining the ability to destroy U.S. Minuteman sites. A New York Times article pointed out that Administration officials had claimed that the U.S. MIRV would be useful only for a retaliatory blow at Soviet cities rather than a first-strike at Soviet missiles. It was planned that 500 Minuteman missiles eventually would be equipped with a triple warhead. Moreover, 31 Polaris submarines each carrying 16 Poseidon missiles, would be MIRVed; the Poseidon was said to carry 10 to 14 warheads, each 40-50 kilotons. The Soviets, it was reported, were known to have been testing a 3-part multiple warhead for the SS-9 for over a year. Each warhead was said to have been the equivalent of a 5-megaton payload.

Apparently the Seamans' announcement regarding MIRV deployment had been unintentionally made, and had "slipped through somehow," according to Administration sources. Press reports also indicated that the prevailing view in the Administration was that it was too late and too difficult to achieve a ban on MIRV testing or deployment. Thus, there seemed to be further evidence that a SALT agreement would probably limit the number of Soviet and American ICBM launchers, although it was also reported that the President had made no final decisions on specific 
March 12:

(cont.)

March 12: proposals for the Vienna talks.

Nonetheless, an additional factor entered into the situation, when it was reported in the New York Times that the Soviets might be amenable to the idea of a moratorium on MIRV testing or deployment. Apparently, Soviet Ambassador Dobrynin and an Embassy minister, Yuri Vorontsov, on separate occasions had mentioned the possibility during informal conversations with some U.S. Congressional aides. Allegedly the Soviets had shown no interest in the topic during the Helsinki discussions. Although some observers did not doubt the sincerity of the Soviet interest in spite of the manner in which it had been conveyed, others suspected that the hints may have been made only to strengthen the arguments of Congressional critics of the Administration's weapons programs.

In a speech on the Senate floor, Senator John Tower cited various figures on the Soviet ICBM (particularly the SS-9) deployment, in order to make the point that "there is ample evidence to believe that the Soviet Union is proceeding to develop a first strike capability." He advocated the $A B M$ system as a means to insure "that no first strike can neutralize our Minuteman force," thereby deterring the possibility of Soviet attack. Moreover, he expressed the view that the previous year's decision to proceed with the Phase I of the ABM had been instrumental in bringing about the initiation of SALT. Based on the assertion that the ABM may have been "the single most valuable aid our negotiators have," it was Tower's view that if the U.S. did not proceed with Phase II of Safeguard, "any other course...would ignore the mounting Soviet threat and undercut the President's ability to negotiate an arms limitation." 
Soviet newspaper Izvestia published an article by chief editor Tolkunov, in the second significant commentary on SALT within the week. (The earlier article appeared in Pravda on March 7; since it was signed only "Observer," Western diplomats in Moscow thought it might have been written by a high Soviet official, possibly Semyonov, head of the Soviet SALT delegation). Both commentaries criticized Secretary of Defense Laird's pronouncements regarding plans for U.S. weapons systems, and the Nixon decision to proceed with phase 2 of Safeguard. The Izvestia article also disapproved of the U.S. MIRV deployment, and went into considerable detail in its questioning of Nixon's use of the term "sufficiency" to describe his Administration's strategic goal. Tolkunov claimed that because of the influence of the military-industrial complex and men such as Laird, it appeared that the U.S. sought "superiority" over the Soviets. Tolkunov asserted that using the talks as a cover for a stepped up arms race would not succeed and would only hamper arms control efforts. Both articles discounted the Soviet threat as "mythical."

American reaction to the two articles varied. One Western diplomat was said to have found the propagandistic tone of the earlier article disturbing, since it might evoke a U.S. response in kind, and thus exercise an adverse effect on the atmosphere of the talks. Officials of ACDA were said to believe that the article would not affect the U.S. negotiating position. The appearance of the second article may have emphasized a Soviet interest in influencing U.S. public opinion against ABM and MIRV. But it was also reported that the article might have indicated a Soviet willingness to negotiate a technology freeze at the Vienna talks. Moreover, the two commentaries may have marked an attitude of Soviet diplomats that by proceeding with the ABM, the U.S. had violated an "unwritten agreement" not to move ahead with new weapons development during SALT. However, some observers found it encouraging that the earlier article had quoted an article by McGeorge Bundy, who had written: "Nothing in the national interest, the ideology or the personal political position of any leader in either country can be advanced by any strategic 
LRS -51

March 14:

(cont.)

March 16: nuclear exchange. No weapons system now in sight for either side can change that fact." On March 14, Red Star published a similar commentary, which sharply criticized MIRV as a threat to SALT, and led some diplomats to believe that the remarks were made to offset the impact of world public opinion on U.S. claims regarding the Soviet SS-9's.

The Senate Foreign Relations Subcommittee on Arms Control, International Law and Organization, chaired by Senator Gore, conducted hearings, where Senator Brooke testified on S. Res. 211, the measure which proposed the mutual MIRV testing moratorium. In the course of his testimony, Brooke offered an amendment which would recommend a halt in deployment, as well as testing of the multiple warhead. Brooke pointed out that "our intelligence evaluation now indicates that the multiple warhead tests of the SS-9 have not yet demonstrated the accuracies required to threaten the Minuteman force. Years of additonal testing are considered necessary, and probably major design changes as well." He added that U.S. MIRVs had not been developed to the point where they could "present a threat to [Soviet] hard targets." Since extensive testing was required on both sides in order to improve accuracy and reliability, the testing moratorium was still a feasible method by which the two countries could prevent deployment of what might appear to be a force intended for a first strike capability. To answer arguments that the U.S. MIRV was being developed in response to the Soviet ABM system, he said that that system had not materialized; rather, Soviet ABM launchers had remained "at we1l under 100 for several 
March 16:

(cont.)

March 17:
Further hearings on S. Res. 211 and on SALT and arms control in general were held on the following dates: April 8 (Herbert York and McGeorge Bundy testifying); April 9 (A. Doak Barnett, and Alice Hsieh); April 13 (Wolfgang K. H. Panofsky, Dr. Herbert Scoville, Adrian S. Fisher); May 18 (Secretary of Defense Laird); May 28 (Joseph Clark, George Kistiakowsky, Jerome Wiesner, and Donald Hornig); June 4 (Director of Defense Research and Development Foster); and June 29 (Dr. Sidney Drell and Dr. M. D. Goldberger). The published record of these hearings was entitled "ABM, MIRV, SALT and the Nuclear Arms Race."

Secretary of State Rogers appeared on the TV program "Today," where he commented briefly on the proposed resolution for a MIRV testing moratorium and the announcement regarding U.S. MIRV deployment. With regard to the former, he said that there was no indication that the Soviets were stopping their own deployment and testing programs, and "I don't see any reason why we should stop ours unilaterally." (Rogers referred to the moratorium several times as "unilateral"; the Brooke resolution calls for a "mutual" halt in MIRV testing, a fact which was pointed out to Rogers in a subsequent letter from Senator Brooke's office, according to press reports.) He also asserted that the Seamans testimony had not been intended as an announcement. He added that the Soviet Union had been aware of plans to deploy MIRV on the schedule set for July and that "it comes as no shock to them." 
LRS -53

1970

March 19:

In an unscheduled press conference, Secretary of Defense Laird said that the Soviet Union had resumed deployment of its Galosh ABM system around Moscow, and were improving the system. According to Laird, the missiles were located in four sites and totalled 64 launchers. He said that these seemed to be part of an eight-site program which eventually would be composed of 128 missiles. (On March 27, the Washington Post reported that while figures on the American ABM system had not been released, it was believed the full 12-site program would involve 1,000 missiles.) Particular details as to performance of the Soviet ABM were not disclosed, but according to a Washington Star report of "Pentagon sources," the missile was believed to be capable of "loitering" in space before striking at an incoming missile, a capability which the American $A B M$ did not possess at the existing stage of development.

Laird also contended that testing of Soviet ICBMs and $A B M s$ had increased since the Helsinki talks. Moreover, Laird said, "they are continuing construction -- new construction -- at ICBM sites."

March 20:

The Senate Foreign Relations Committee met in executive session to consider S. Res. 211; the resolution, as amended, was passed by a vote of 10-0. Of two resolving clauses, the first proposed that negotiations between the U.S. and the USSR "to seek agreed limitations of both offensive and defensive strategic weapons should be urgently pursued." The original wording of the second clause, was changed as the result of an amendment offered by Senator Cooper. Rather than a suspension of MIRV testing, the resolution urged the President to propose to the Soviet Union that both countries immediately suspend "further deployment of all offensive and defensive nuclear strategic weapons systems, subject to national verification or such other measures of observation and inspection as may be appropriate." It was also decided by the committee to note in its report that the most effective method of preventing further deployment of MIRV was the suspension of further flight tests "subject to national verification or other measures of observation and inspection." 
LRS -54

1970

March 20:

(cont.)

The Committee report on the resolution (dated March 24) also stated the committee view that "a general halt in the deployment of all strategic weapons is more secure against significant evasion than a more limited suspension would be." This conclusion was based on the assertions that it would be easier to monitor an overall freeze, rather than a specific limited one, and (2) substantial evasion would be necessary in order for one party to gain significant advantage over another. The report described the effect of the resolution as one which urged the President "to seek an agreement at the outset of negotiations which would freeze...escalation" of the arms race. The resolution would also serve as an indication of Senate support "in such efforts."

The New York Times also reported that Senator Brooke had favored the change in the wording of the resolution and that he had discussed it with the President the previous evening. Brooke hinted that the resolution "might have some impact" on the President since it indicated Senate willingness "to share the burden of political responsibility" in proposing the freeze.

March 21:

When questioned in a press conference about the Brooke resolution, President Nixon said that as he understood it, the resolution "simply says that the United States and the Soviet Union should try to negotiate a freeze on offensive and defensive missiles." Pointing out that "that is what SALT is all about," he said "I think the resolution really is irrelevant to what we are going to do." While he expressed hope that an arms control arrangement could be made with the Soviet Union, he said that "it is somewhat more intricate than the resolution would imply." He described the Soviet Union negotiating technique as one which did not use "generalized language," rather, "they came in with very precise weapon systems by weapon systems analysis." He said the U.S. was prepared for either a comprehensive agreement or a system-by-system agreement. 
LRS -55

1970

March 23:

Secretary of State Rogers was also asked in a press conference to comment on the Brooke resolution. Calling it "largely a paraphrase of what is in the NPT," he said that the objective of the resolution "is a good one." But, he added, "how we negotiate should be left to the negotiators." In response to a question on the impact of MIRV on SALT, he stated that he did not think it was "too late to have any kind of an agreement." He also said that the Soviet Union had not stopped any of its deployments, which had been "very impressive."

March 25:

The National Security Council (NSC) held a meeting on SALT, and two days later it was reported by the Washington Post that the Joint Chiefs of Staff (JCS) had opposed any move to curb MIRV or ABM. It was also reported that because of concern for the budget, President Nixon was hoping to make offers in Vienna which would avoid costly expenditures on new weapons systems. No final decision had been made by the President, however, and the possibility of proposing either an ABM or a MIRV curb had not been eliminated.

The Post report stated that disagreement remained within the Administration regarding the feasibility of halting MIRV deployment. In addition, a number of different SALT proposals were being discussed. The "minimum" American proposal, the report stated, would be a freeze on Soviet and American land-based ICBMs; some Pentagon officials were said to object to this arrangement since the number of Soviet ICBMs exceeded the U.S. total.

According to the report, the fact that the JCS opposed a reduction in the full 12-site ABM program had been criticized within the Administration. Because the full U.S. program was thought to involve 1,000 missiles, the resulting imbalance with the Soviet program (at present 64 missiles, and a projected final figure of 128), would make the JCS position "untenable" in negotiations. An additional complication arose over the continuing Soviet submarine program, which included 110 submarine launched 
March 25: (cont.)

March 29: missiles (as of September 1, according to Secretary of Defense Laird), as compared with 45 the previous year. (The American total remained at 656.) Moreover, a new Soviet construction site for submarines recently had been detected by the U.S. Thus, because of these developments, some officials within the Administration believed a SALT pact would have to include a limitation on Soviet submarines.

In a column in the Washington Post, Joseph Kraft disclosed that there was considerable dispute within the Administration regarding U.S. SAIT proposals for Vienna, particularly over the U.S. ABM. Kraft reported that U.S. chief negotiator Smith had been opposed to the view taken by the JCS, the leading group which supported the full ABM program. According to Kraft, the key to success in SALT relied on the U.S. being prepared to abandon its ABM in order to avoid a new round in the arms race. It was also reported that Secretary of State Rogers had taken more of a "halfway position," i.e., that deployment of the ABM should proceed slowly, but the U.S. should remain prepared to abandon it, if the Soviets stopped the deployment of their own $A B M$ and offensive missile systems.

In a Chalmers Roberts column on the same day, there was additional speculation with regard to the ongoing discussions within the Administration. Roberts reported that the State Department supported maintenance of U.S. general purpose forces, especially those in NATO, thereby avoiding too heavy a reliance on nuclear weapons for defense of Western Europe. This issue was described as having some bearing on SALT. If the talks were not successful, more money would have to be spent on new weapons system. With an increase in these expenditures, the Administration might be forced to reduce troop levels, an event which would lead to a situation where only nuclear weapons were available in Europe. In any case, the financial burdens of a stepped up arms race were expected to exercise substantial influence on the President's final decisions for U.S. SALT proposals in 
March 29:

(cont.)

March 31:

April 8:
Vienna. Roberts also reported that concerning recent reports of a change in Moscow's attitude toward limitations on MIRV and ABM, Soviet diplomats had said that their remarks had been taken out of context and reported incorrectly.

The Associated Press reported that a few days earlier, the Soviet Union had tested two SS-9's, each with a triple warhead, in the northwest Pacific. While these were the first Soviet tests announced by the United States since the spring of 1969 , the report stated that according to Pentagon figures, there had been 30 Soviet tests of a variety of missiles since the opening of SALT, twice the number of U.S. tests for the same period. A Pentagon spokesman said that the Soviet Union had tested more than a dozen SS-9's over the past two years. One spokesman was reported to have said that the Russians "could be approaching the point at which they could make a deployment decision with this series of tests."

In the midst of the Senate debate on the Brooke resolution, President Nixon met with the National Security Council for two hours to discuss SALT. As reported in the Washington Post, the decision now left to the President was whether to seek a limited or comprehensive agreement. It was expected to be the latter, an arrangement which would include some curb on MIRV and ABM, and thus present certain difficulties with regard to inspection. Nevertheless, the idea of proposing a comprehensive agreement reportedly had been recommended by the General Advisory Committee of the U.S. Arms Control and Disarmament Agency. (The previous day, the New York Times reported that the Committee had recommended a halt in deployment of offensive and defensive missile systems, a claim which had been refuted by Chairman John J. McCloy.) Other arms control recommendations had been made to the President during the previous week by groups such as the American Assembly and the Senate Democratic Policy Committee, both of which had supported 
April 8: (cont.)

Apri1 9: an interim halt in deployment while a permanent arrangement was negotiated in SALT. In a related development, on April 7, Senate Republican leader Hugh Scott endorsed the Brooke resolution, becoming the 5lst co-sponsor of the measure.

According to the Post, there was no possibility that the President would approve a moratorium, for two reasons: (1) the U.S. might become "locked into an open-ended freeze" by U.S. public opinion and (2) verification methods were not adequate to ensure Soviet compliance with such an agreement. The Post report also noted that Presidential advisors felt that a number of decisions would be held open until the Soviets gave some indication of their own proposals. In this area, an important consideration was to what degree the Soviets would find an $A B M$ necessary against the Chinese threat.

The Senate approved the Brooke resolution by a vote of 72-6. (For details of the resolution's provisions, see March 20, above.) In the course of debate, Senator Muskie proposed a "negotiator's pause," or a mutual halt in all MIRV and MRV testing, and deployment of all weapons systems, with an automatic lapse after six months if a formal agreement had not been negotiated. The Brooke resolution itself imposed no time limit, although Brooke stated that the President could end the suspension at any time he deemed it an "undue danger to our national security." The fact that there was no provision in the resolution for a time limit on the freeze was expected to be a key point in Administration criticism, in addition to its objections regarding adequate verification of a MIRV testing moratorium. The New York Times noted that the thrust of the Senate argument centered on the goal of "seizing the psychological initiative" by proposing the halt at the outset of the talks. 
April 11:

The Institute for Strategic Studies released its "Strategic Survey 1969," in which it was stated that "the increasing accuracy of nuclear missiles presents an even grater threat to the strategic balance than... MIRV." The report noted that improvements in the guidance of missiles can have a much greater effect on efficiency than an increase in yield. An awareness of this fact, the report said, has "aroused fears that either the Soviet Union or the United States might hope to destroy the bulk of the other's ICBMs by a surprise attack." According to the report, this situation raised serious questions as to the future of land-based ICBMs, since "it begins to seem possible that no amount of protection for ICBM silos can compensate for the improvements in accuracy now in prospect." It was also asserted that area ABM defense might "loosen the restraints of deterrence," if it were believed that the system could withstand a major retaliatory strike. The report described SALT as the "most complicated" negotiations in arms control history; MIRV was considered a factor which would make agreement difficult, as well as the fact that consideration of the Chinese threat "may...make it mutually unacceptable to eliminate the ABM defense of civilian population."

Apri1 11:

The President met with the U.S. SALT negotiators for 50 minutes to give them final instructions for the talks. White House Press Secretary Ziegler said that the team was going to Helsinki with a "constructive attitude" and that "they are going there to accomplish something." It was also announced at this time that J. Graham Parsons, former envoy to Sweden, would serve as an assistant to Llewellyn Thompson, whom he eventually would replace in the negotiations. The delezation was scheduled to leave on April 13 for consultations with U.S. NATO allies in Brussels, while en route to Vienna. 
April 12:

The Washington Post reported comparative figures for the years 1965, 1968 and 1969 on Soviet SS-9 deployment, to indicate an upsurge in activity. According to reliable Pentagon sources, the Soviets deployed about 70 SS-9's in 1965; deployment eased off in 1968 to between 30 and 40, but the number increased to over 50 in 1969 . At this point it was believed that the Soviet Union had 225 SS-9's operational.

Apri1 13:

According to a report from London by UPI, Communist diplomats had hinted that the Soviet SALT proposals involved a freeze of both offensive and defensive nuclear missiles as a first step toward broader limitations. However, the report noted, the Soviets apparently were "cool" to the idea of a MIRV or MRV testing moratorium, because of suspicions that the U.S. had a substantial lead over the Soviet Union in its development. The New York Times remarked that because of the various political and technical objections which the Administration had raised wth regard to the moratorium approach, it seemed doubtful that the U.S. would respond favorably to such a proposal.

Apri1 13:

U.S. SALT negotiators left for Vienna, with a stop in Brussels en route, in order to have consultations on the talks with U.S. NATO allies. Press reports speculated on the U.S. negotiating position as being one which stressed caution and flexibility. New York. Times noted that no consultations had been held with Congressional circles prior to the delegation's departure. Both the Times and the Post reports advanced that considerable time would be spent in Vienna on settling on details which were left open at the end of the Helsinki discussions, before actual bargaining took place.

Apri1 14:

In a televised speech on various foreign policy issues, Soviet Communist party leader Leonid Brezhnev said that the USSR would welcome "a reasonable agreement" with the United States in SALT. However, he also warned that if anyone sought military superiority over the Soviet Union "we will reply with the necessary increase in military might that guarantees our defense." Brezhnev noted that if the Administration were sincere in its 
April 14:

Apr11 14:

Apri1 16: desire to restrain the arms race and if American public opinion could overcome the increasing pressure of the arms manufacturers and the military, the prospects for agreement appeared "favorable." The New York Times described his remarks as "the strongest indication so far of the Soviet uneasiness" over U.S. decisions regarding its $A B M$ and MIRV deployment.

Both the American and Soviet SALT delegations arrived in Vienna, with the leader of each group making a brief statement. U.S. chief negotiator Smith distinguished between the Helsinki and the Vienna talks, calling the earlier discussions "exploratory in nature," the current ones, "the actual negotiations." He said that the U.S. proposals would be made in "a reasonable time." Ambassador Semyonov stated that the Vienna talks were a continuation of those in Helsinki, and added that his government was entering them in a "businesslike and constructive spirit." It was expected, according to the Washington Post, that it would be at least two weeks before any formal proposals were made. Both Smith and Semyonov met the following day for preliminary discussions of procedural problems, prior to the formal opening on the $16 \mathrm{th}$.

The second phase of SALT opened in Vienna, in a 30-minute formal ceremony in the Belvedere Palace. As was the case in Helsinki, the head of each delegation made brief opening remarks. Mr. Semyonov recalled Brezhnev's April 14 speech, referring to his remark that Moscow would welcome a "reasonable accommodation" and would "do its best for these negotiations to be useful." He expressed his hope for curbing the arms race, "the intensification of which serves the interest of aggressive imperialist circles," a remark which press reports labelled a slight departure from the cordial atmosphere in Helsinki. Smith read a message to the U.S. delegation from President Nixon, who reaffirmed his remarks in a similar statement in November. He hoped for an agreement "on the limitation and eventual reduction of strategic arsenals with proper recognition of the legitimate security interests" of both the U.S. and the Soviet Union and third countries. 
LRS -62

1970

Apri1 16:

He added that "your current instructions will enable you (cont.) to move from general explorations to a discussion of more specific proposals toward these ends." Moreover, he gave the negotiators "the authority to approach the issues in the most comprehensive manner." The first working session was scheduled for the following day in the Soviet Embassy; since Semyonov would act as host, he would be the first to speak. The second session was scheduled for April 20, in the American Embassy.

The New York Times reported that on the same day as the formal opening of the talks, President Nixon met with Congressional leaders for a two-hour briefing on his negotiating position for Vienna. Following the meeting, Senate Majority leader Mansfield called the proposals "very sound and worthwhile," and Senator Gore described them as "a comprehensive treatment of all phases of both defensive and offensive weapons." Senator J. W. Fulbright also attended. The Times also reported that in the course of the briefing, Nixon indicated that he had been influenced by Senate approval of the Brooke resolution. Nevertheless, Nixon's final word on U.S. SALT proposals was said to have fallen short of a moratorium on deployment while a permanent arrangement was negotiated.

According to Administration and Congressional sources, as reported in the Times, Nixon's instructions to his negotiators had been to press for a comprehensive agreement rather than a weapon-by-weapon approach. The concept might include relatively small $\mathrm{ABM}$ systems and a ceiling on the number of offensive strategic weapons. Both the Times and the post noted that in deciding on the U.S. negotiating position, there had been considerable uncertainty regarding expected changes within the Soviet politburo. It had appeared that Brezhnev was becoming more of a dominant figure, an occurrence which might result in a stiffer Soviet attitude toward SALT, although there was no hard evidence of the change in Kremlin leadership. 
LRS- 63

1970

April 16:

(cont.)

Nonetheless, the Times reported, it was finally decided to offer a comprehensive proposal, on the grounds that if it were rejected, the U.S. could revert to individual weapons systems proposals. One criticism of using this latter approach at the outset of SALT was that Soviets might select a combination of proposals which would be unsuitable to the U.S. 